\title{
角膜形状解析装置測定上の注意点
}

\author{
大島 順子 - 田中 俊一 ・清水 公也
}

武蔵野赤十字病院

\section{Successful maneuvers on Corneal analysis system}

\author{
Junko Ooshima, Shunichi Tanaka, Kimiya Shimizu \\ Musashino Red Cross Hospital
}

\section{要 約}

角膜形状解析装置 EyeSys 社 corneal analysis system 3 年間使用した過程で遭遇した，以 下の具体的な問題点と解決策について検討した結果，（1）（5）の結論が得られた。

（1）角膜に触れる他の検査との順序を考慮する。

（2）沪液層の厚さを適度にするために測定直前に瞬目させる。

（3）小瞼裂眼では，眼瞼を無理に開瞼しょうとして，眼球に圧迫を加えたり下眼瞼まで引 き上げないようにする。

特に奥目では，紙絆創膏を巻いた綿棒の使用が有効である。

（4）測定眼が視力不良の場合，僚眼を遮蔽，またはプラチドリング上にあるマークを利用 して固視を誘導する必要が生じる。

（５）コンタクトレンズ装用眼は，最低 1 週間の装用中止後の測定が望ましい。

\section{Abstract}

We studied and discussed some problems we experienced during three years' use of the EyeSys Corneal Analysis System, so that further improved maneuvers might be obtained.

The problems and the improved maneuvers are as follows;

1) Because corneal topography is to be measured prior to any tests that may possibly affect the corneal shape, it is required to set an order of various tests properly so that the corneal topography may be measured correctly.

2) In order to adjust the tear-layer thickness idealy, you must tell your patient to blink once immediately before the corneal topography is measured.

3) When corneal topography is measured on an eye with a narrow palpebral fissure, you should neither press the eye ball hard, nor lift up even the lower lid unnecessarily when you have reason to force the eye to open.

Especialy for a deep-set eye, the use of a paper-bandage wrapped Q-tip is helpful to manipulate the eye lid.

4) If VA of the eye is so poor, there may be cases which the fellow eye should be either occluded or led to gaze at the $\mathrm{X}$ mark set by the platido-ring for fixation.

5) In case of a contact lens wearer, you must tell the patient to discontinue lens wearing for oneweek or longer prior to measuring the corneal topography of the eye.

連絡先（下180）東京都武藏野市境南町 $1-26-1$

武蔵野赤十字病院眼科 大 島 順 子

Tel. $0422-32-3111$

Key words : cornea, topography, video keratoscope, tear film, deep-set eye, contact lens 


\section{I ． 緒言}

角膜乱視の測定法としてケラトメータから得 られるシンプルな数字（屈折力とその角度）は， 従来から眼科に携わる者にとって唯一絶対的な ものであった。近年, 角膜形状解析装置の開発 により角膜全体の形状の変化をカラーマップで 容易に観察できるようになった ${ }^{12) 。 そ れ に よ ~}$ り複雑な変化をとらえることが可能になり, 円 錐角膜の早期発見や, AK (Astigmatic Keratoto my), PRK ( Photorefractive Keratectomy), RK (Radial Keratotomy), 角膜小切開白内障手術な ど, 術前後の検查を含め, 臨床上の応用範囲も 広がった ${ }^{3)}$ 。しかし，その測定方法は現在の装 置の特性や限界を理解していないと大きな誤差 を生じたり，場合によっては，間違った手術を 行ってしまう恐れすらある。そこで今回は，角 膜形状解析における問題点を挙げ解決策を検討 した。

\section{II ． 検查機器およびその測定原理}

EyeSys 社製 corneal analysis system を用いた。 現在，このようなビデオケラトスコープは数社 から開発されているが，その測定原理はどの機

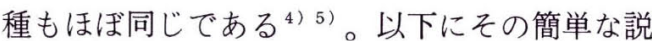
明をする。

検査は，ビデオケラトスコープを用いてマイ ヤ一像を写し出し，その像の大きさを測定する ことにより角膜曲率半径を算出するが，全体的 な角膜形状を表現するためにはマイヤー像の中 心から放射状に何点か測定点をとり（EyeSys は360×16点), 各部の屈折力を求める。この断 片的な情報をもとに，その間を補完してトポグ ラフィーを作成する。このようにして得られた トポグラフィーは, 角膜屈折力の大きい所を赤 やオレンジの暖色系に，小さい所を青や紺色の 寒色系としてカラーマップで表される（図 1)。 どの色がどのジオプターに対応するか, カラー 変化の間隔はどのようになっているかは，カラ ースケールで確認することが大切である。スケ ールには, 絶対表示, 相対表示, ステップ幅固 定表示とあるが, 今回はより細かい変化をとら えられる相対表示で説明する。

\section{III. 方法・対象}

平成 3 年 6 月から平成 6 年 9 月に武蔵野赤十 字病院眼科にて EyeSys 社 corneal analysis system を使用し，16,000回以上の角膜形状解析装置に

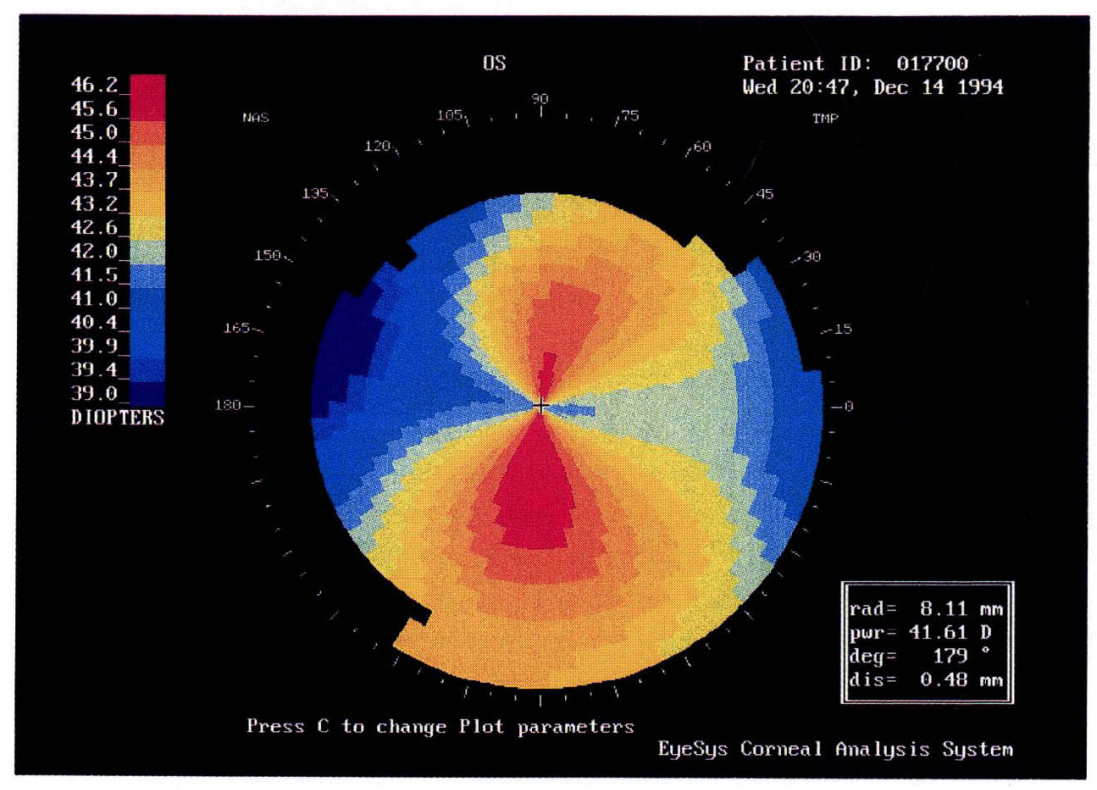

目 1 直乱視眼のトポグラフィー 
よる測定を行った。その上で，特に測定上注意 すべき症例や興味深い症例を対象とした。

\section{IV. 結果・考察}

\section{1. 検查順序}

図 2 は, 角膜内皮スペキュラー検査直後のマ イヤー像である。角膜表面にスコピゾルが付着 し, 角膜中央部の形状の変形も予想される。し たがって，正確なマイヤー像をとらえるために は, 角膜に触机る検查 (圧平式眼圧測定, 角膜 厚測定, 眼軸長測定など）の前に行わなければ ならない。

\section{2. 涙 液}

図 3 は, ドライアイの症例のマイヤー像であ る。固視させている間に角膜表面が乾燥しリン グの境界が不整となり，これでは正確なトポグ ラフィーが計算できない。また，涙液が多い場 合にも，下方に涙液が溜ることや，涙液層の厚 さが不均一になることがあり，同様に正確に測 定できない。涙液の多少にかかわらず，フォー カスを合わせ撮影直前に，一度瞬目させること によってほとんどの。症例は涙液層を適度な厚さ にすることができる。

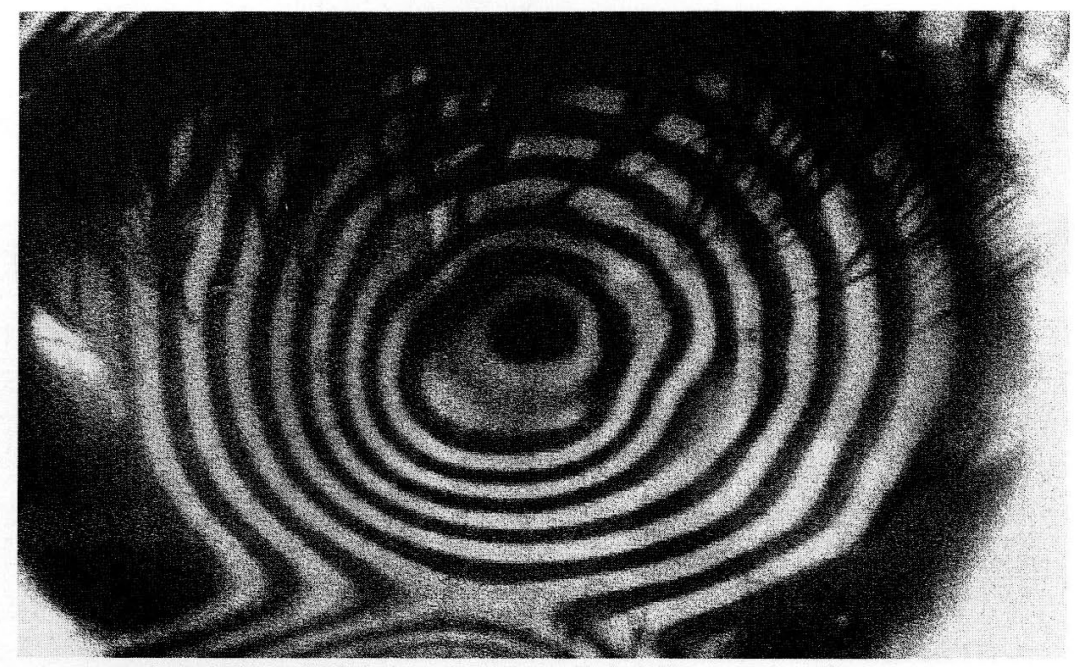

四 2 角膜内皮スペキュラー検査直後のマイヤー像

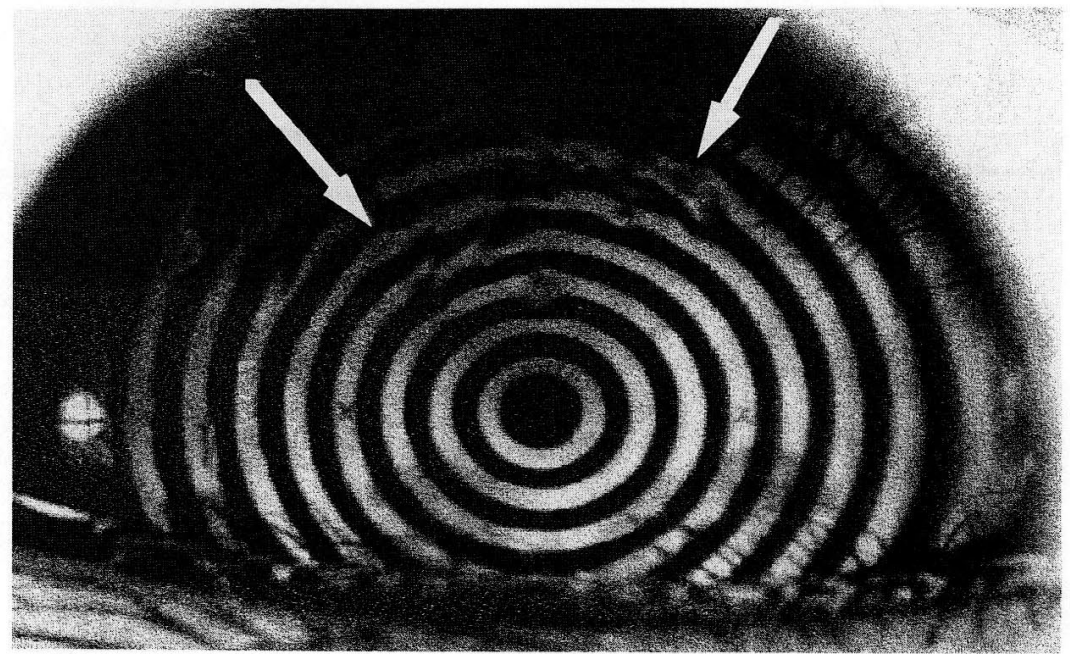

図 3 ドライアイの症例のマイヤー像 


\section{3. 小瞼裂眼}

瞼裂が狭い場合，指によって開瞼しなければ ならない。白内障術前検査において, 自然開瞼 で測定できる方が稀である。しかし，図4 では, 強く開瞼しすぎたために下眼瞼まで持ち上がり, 角膜下方部が測定不能となっている。さらに, 眼球に圧迫が加わっているために上下にスティ ープ化した領域が出現している。同じ症例を図 5 では, 人為的に角膜を変形させることなく, かつ，角膜を完全に露出させるよう，できるだ けそっと上眼瞼を持ち上げて測定した。このよ うに，指による開瞼で十分な場合も多いが，そ れでもうまく行かない場合の解決策は次に述心゙ る。

奥目で瞼裂が狭い場合，高い鼻の影や眼瞼を
上げている指の影などが写ってしまい，その部 分のマイヤー像が欠けてしまうことがよくある (図 6 )。その対策として，まず，紙紏創膏で 瞼を吊り上げてみたが測定までに角膜表面が乾 燥してしまった。次に，硝子棒や綿棒であげて みたが先が滑りやすくうまくいかなかった。現 在は, 荻野の報告 ${ }^{6)}$ 加得た, “紙絆創膏の粘 着面が外になるように巻き付けた綿棒”を使用 している(図 7 )。簡単に作製でき大変有用で ある。

\section{4. 視力不良眼}

EyeSys は, 直径約 $25 \mathrm{~cm}$ のプラチドリングを 眼前約 $10 \mathrm{~cm}$ から角膜に投影して測定する（図 8 ）。 視力が良好な場合, 中央の緑の点を固視させて 行う。しかし, 白内障術前検査でその混濁に左

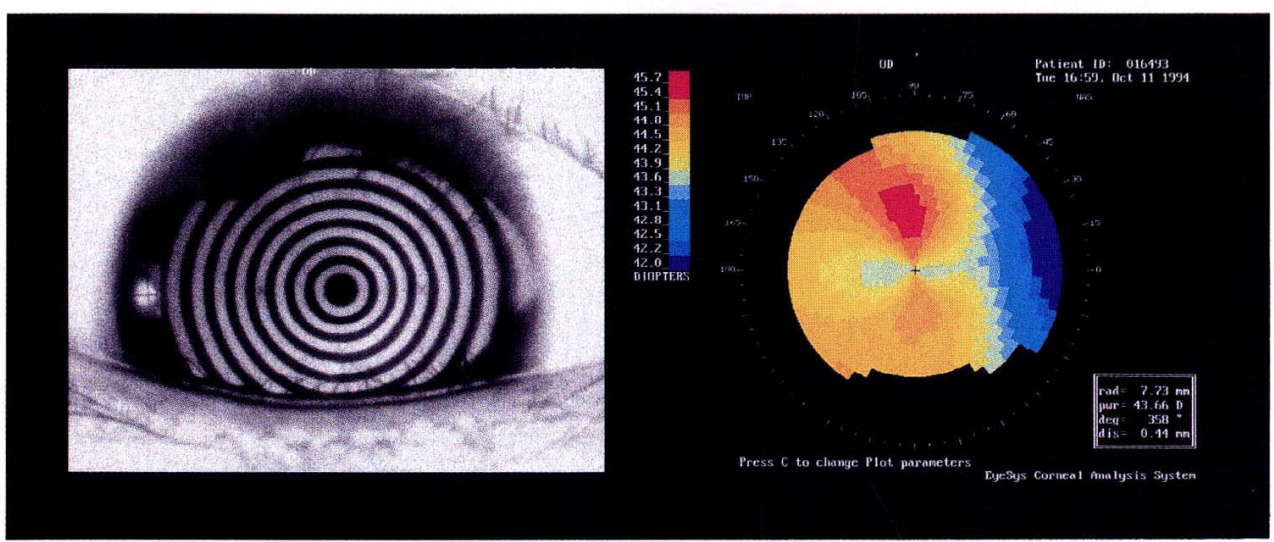

図 4 小瞼裂眼 : 無理矢理の開瞼の例，下眼瞼が持ち上がり，角膜は上下にスティープ化している。

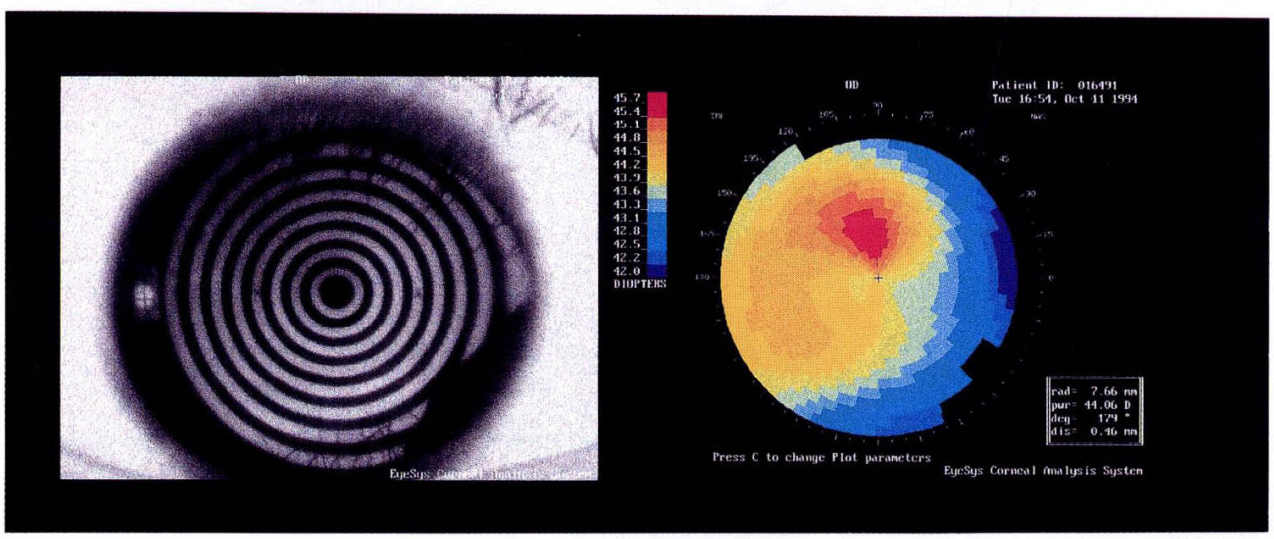

図 5.小瞼裂眼 : 適切な開瞼の例, 上下のスティープ化した領域が軽減している。 


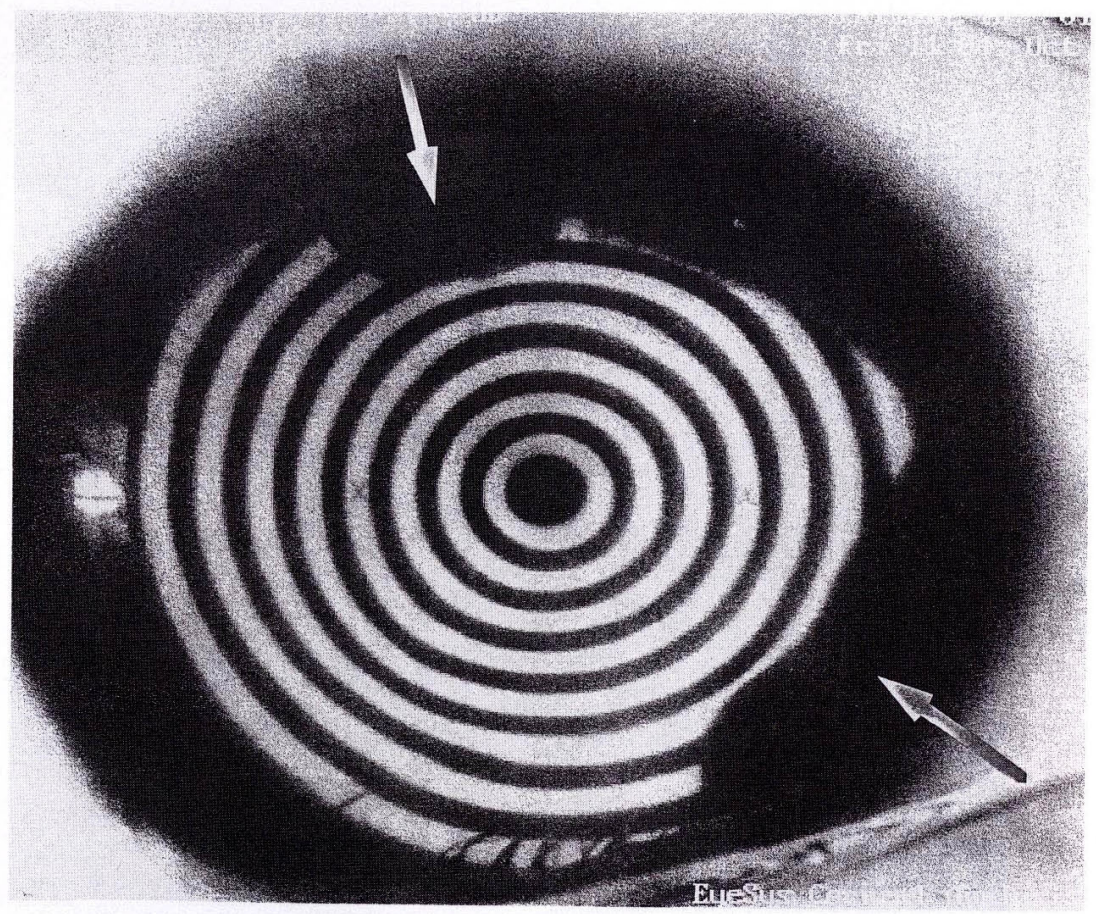

図6 奥目の症例のマイヤー像。下の矢印が鼻の影, 上の矢印が検者の指の影

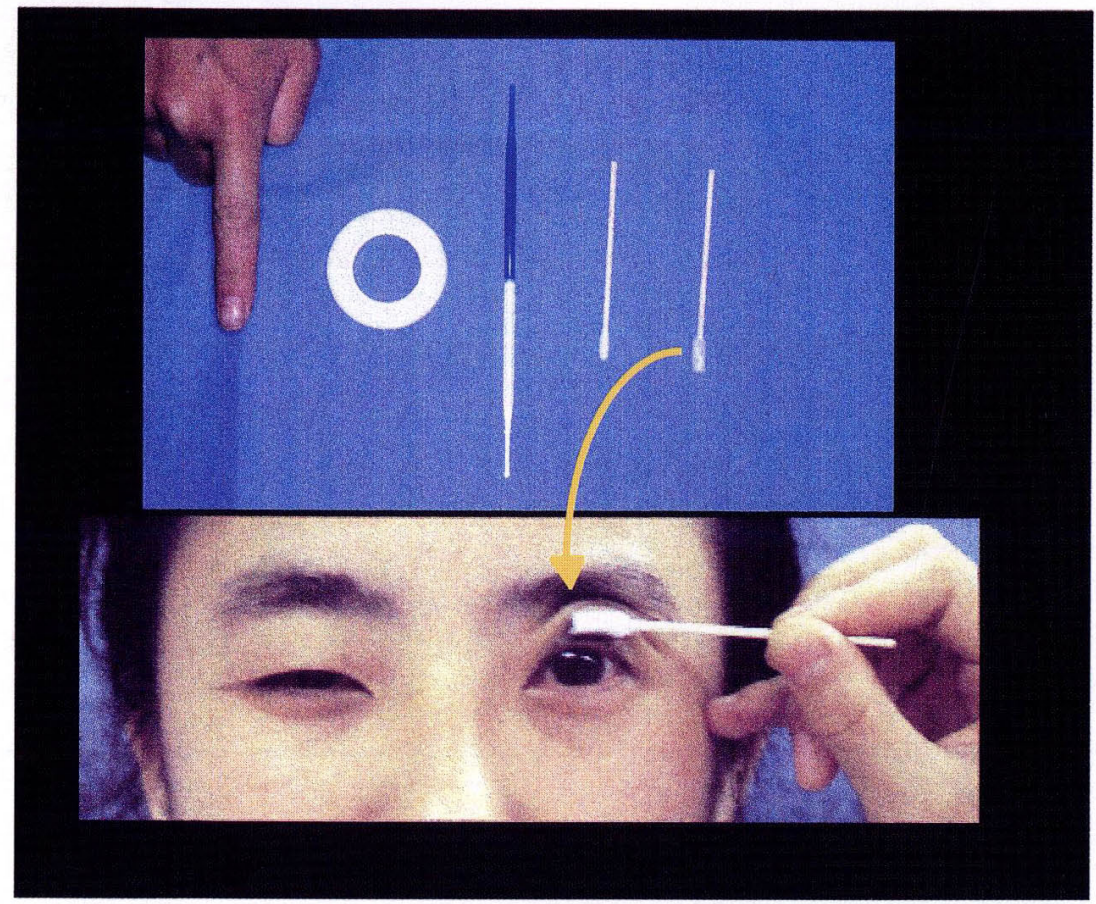

図 7 左から, 指, 紙紏創膏, 硝子棒, 綿棒, 紙紏創膏を巻いた綿棒一下はその使用例 


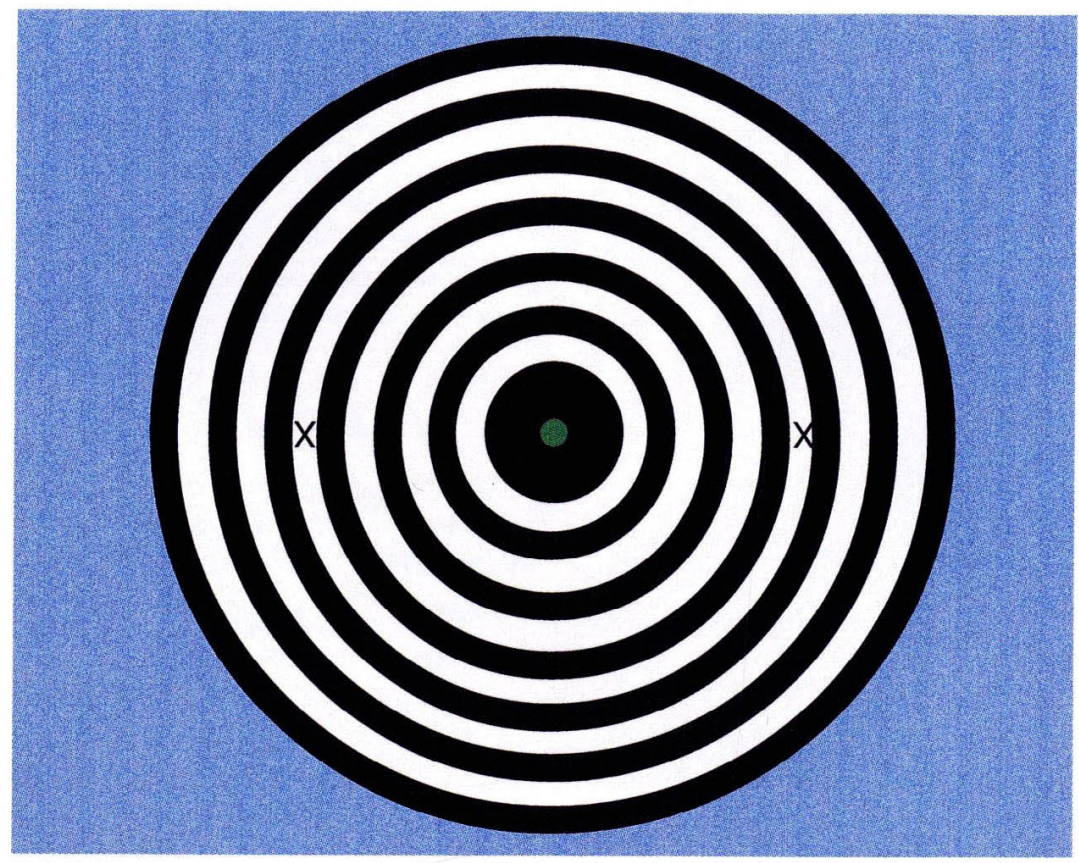

図 8 角膜に投影するプラチドリング

右差があると，固視点が $10 \mathrm{~cm}$ も離れているため に視力の良い方の眼で固視しようとしてしまう。 このため, 測定眼が固視可能な視力なら僚眼を 遮蔽した方がより正確であるし，固視不可能な 視力ならプラチドリング上にあるXマークを利 用して僚眼によって固視を誘導しなければなら ない。

\section{5.コンタクトレンズ}

コンタクトレンズ, 特にハード系コンタクト レンズ装用によって角膜形状の変形が生じるこ とはよく知られている7)。いくつかの角膜変形 のパターンがみられたが, 主に角膜中央部の> ラット化がみられた症例（図9）と，レンズ周 辺部に相当すると思われる位置にフラット化が みられた症例（図10）が多かった。推測の範囲 だが，角膜とコンタクトレンズの間により強い 力が加わっている部位に角膜のフラット化が対 応していると考えられた。

そこで，装用状態は良好であった症例（四10 と同一症例）のコンタクトレンズ装用中止後角 膜形状回復過程を観察した（図11）。装用中止
後 1 日までの角膜の形状変化は大きかったが, それ以降 7 日目までも徐々に変化が続いていた。 このことから, 我々は, 術前検査での角膜形状 解析を行うにあたって, 最低 1 週間のコンタク トレンズ装用中止を原則としている。しかし， フィッテイングが極端に悪かった例やレンズが 固着していた例では, 形状が安定し本来の角膜 に復帰するまでにさらに長期の観察期間を要す ると考えている8)。

一方, ソフトコンタクトレンズでは, 症例に よってばらつきがあり, 今回は明確な結果が得 られなかった。

\section{V. 結 論}

今後, 角膜形状解析は, 角膜診療における診 断や術前術後の評価など, 幅広く臨床応用され ていくと思われる。まだ新しい検査法であるの で, 結果に誤差を及ぼす種々の問題点とその解 決法などを十分理解した上で検査が行われるこ とが重要である。 


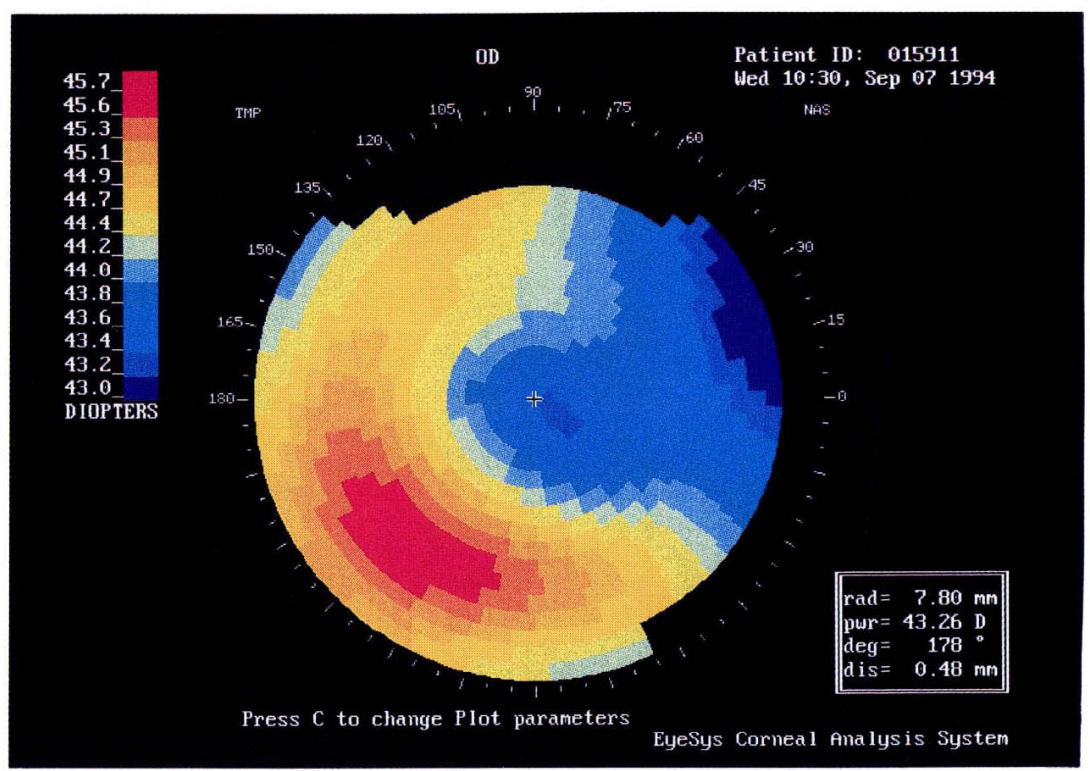

図 9 ハードコンタクトレンズによる角膜中央部のフラット化

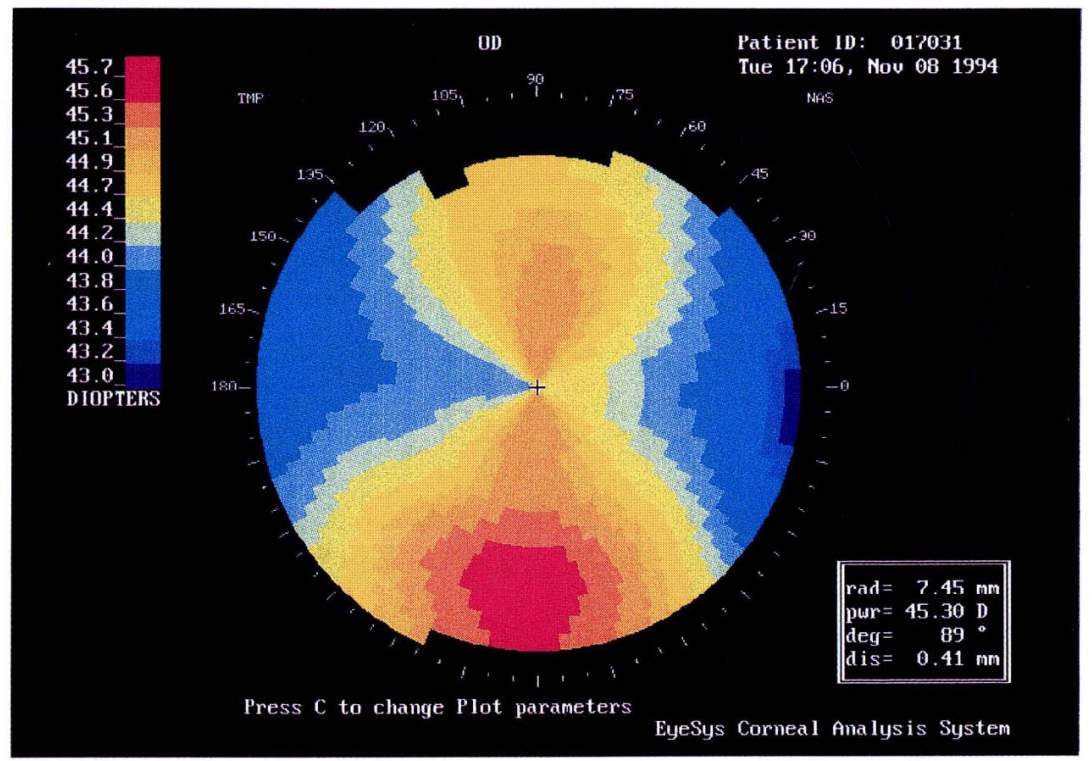

四10 ハードコンタクトレンズによるレンズ周辺部に相当する部分のフラット化 

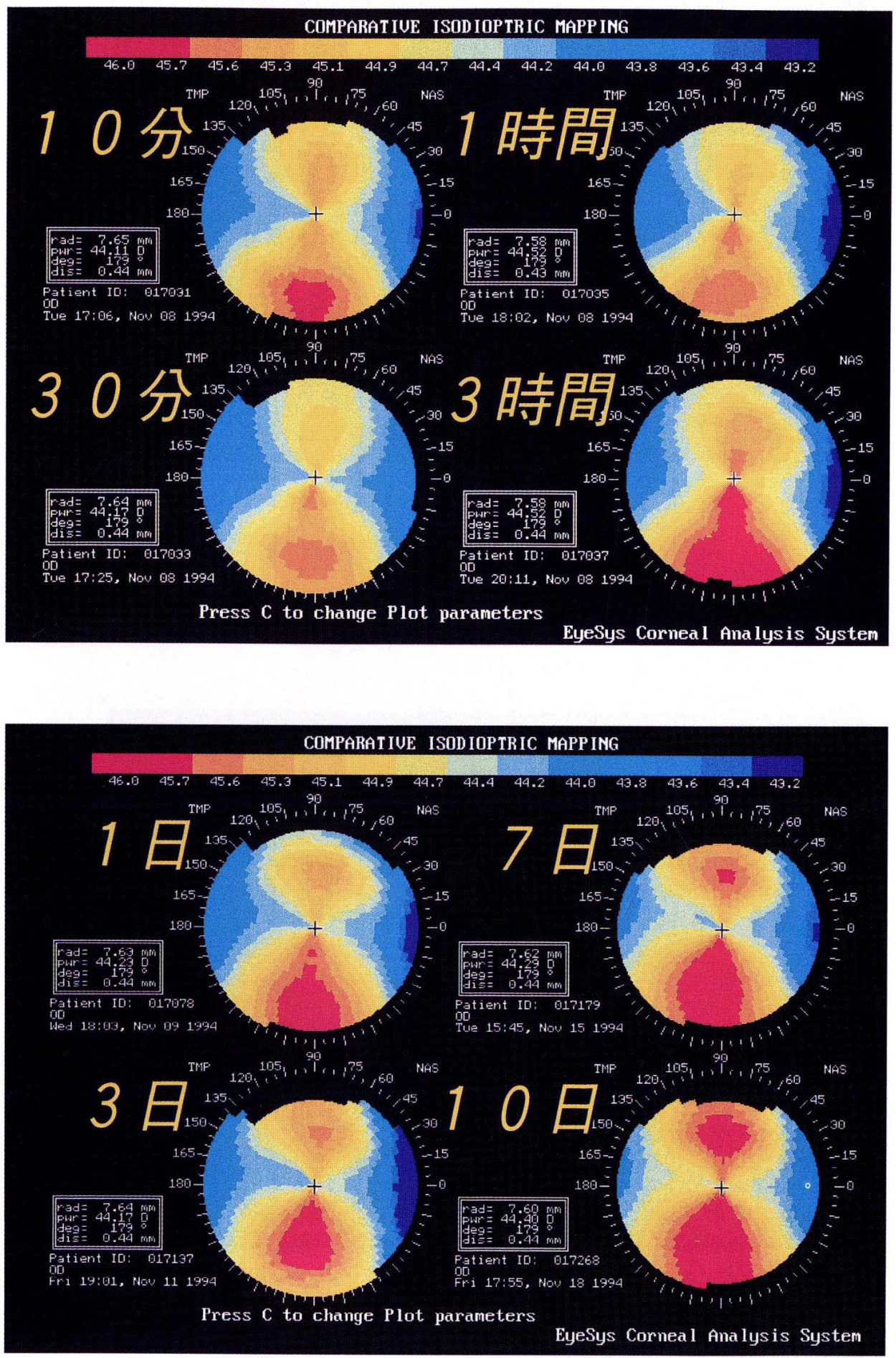

図11 ハードコンタクトレンズ装用中止後の角膜形状変化 


\section{文 献}

1) 池沢暁子, 宮田和典, 他 : 白内障手術後角膜 の形状解析 (第 1 報). 臨眼, $44: 498-499$, 1990.

2 ) 池沢暁子, 宮田和典, 他 : 白内障手術後角膜 の形状解析 (第 2 報)。臨眼, $45: 39-43$, 1991.

3) 田中俊一, 清水公也 : マトリックス平均法に よる角膜形状解析（切開部位別術後乱視の検 討). 眼科手術, $6: 13-24,1993$.

4 ）宮田和典： Corneal Topography. あたらしい 眼科, $8: 1113-1114,1991$.
5 ) Donald R. Sanders\&Douglas D. koch:An Atlas of Corneal Topography: 1-30, SLACK Inc., Throfare,NJ, 1993

6 ）荻野紀重 : 圧平眼圧計による計測時の眼瞼の 上げ方についてー計測困難な時の工夫－。日 本の眼科, $65: 1149-1151,1994$.

7 ) 前田直之 : 屈折矯正手術における角膜形状解 析.あたらしい眼科, $11: 213-219,1994$

8 ) Steven E. Wilson, Stephen D. klyce:Screening for Corneal Topographic Abnormalities before Refractive Surgery, Ophthalmology Vol 101, No. 1 : 147-152, 1994. 